Published in final edited form as:

J Membr Biol. 2004 September 1; 201(1): 25-32.

\title{
Localization of $\beta_{1}$-Adrenergic Receptors in the Cochlea and the Vestibular Labyrinth
}

\author{
C. Fauser, S. Schimanski, and P. Wangemann \\ Cell Physiology Laboratory, Anatomy \& Physiology Department, Kansas State University, \\ Manhattan, KS 66506, USA
}

\section{Abstract}

Sympathetic activation in a "fight or flight reaction" may put the sensory systems for hearing and balance into a state of heightened alert via $\beta_{1}$-adrenergic receptors $\left(\beta_{1}\right.$-AR). The aim of the present study was to localize $\beta_{1}$-AR in the gerbil inner ear by confocal immunocytochemistry, to characterize $\beta_{1}$-AR by Western immunoblots, and to identify $\beta_{1}$-AR pharmacologically by measurements of cAMP production. Staining for $\beta_{1}$-AR was found in strial marginal cells, inner and outer hair cells, outer sulcus, and spiral ganglia cells of the cochlea, as well as in dark, transitional and supporting cells of the vestibular labyrinth. Receptors were characterized in microdissected inner ear tissue fractions as $55 \mathrm{kDa}$ non-glycosylated species and as $160 \mathrm{kDa}$ high-mannose-glycosylated complexes. Pharmacological studies using isoproterenol, ICI-118551 and CGP-20712A demonstrated $\beta_{1}$-AR as the predominant adrenergic receptor in stria vascularis and organ of Corti. In conclusion, $\beta_{1}$-AR are present and functional in inner ear epithelial cells that are involved in $\mathrm{K}^{+}$cycling and auditory transduction, as well as in neuronal cells that are involved in auditory transmission.

\section{Keywords}

Inner ear; Organ of Corti; Immunocytochemistry; Western immunoblot; Deglycosylation; Cyclic AMP

\section{Introduction}

Beta-adrenergic receptors ( $\beta$-AR) mediate a number of organ-specific responses that are part of the "fight or flight reaction". For example, $\beta_{1}$-AR increase heart rate and force and $\beta_{2}$-AR open and moisturize airways and eyes [2,26]. Hearing and the sensation of balance and acceleration may be as important as sight for a successful "fight or flight reaction". The inner ear is well supplied with a vascular and a vessel-independent sympathetic innervation [20], which indicates the importance of sympathetic control. It has been shown that autonomic innervation influences the vascular tone [12]. It is largely unknown, however, what effects in the inner ear result from sympathetic stimulation. Recent pharmacological studies have demonstrated $\beta_{1}$-AR in the cochlea and the vestibular labyrinth. $\beta_{1}$-AR occur in strial marginal cells of the cochlea and in dark cells of the vestibular labyrinth [23,24]. These epithelial cells are responsible for $\mathrm{K}^{+}$secretion and essential for $\mathrm{K}^{+}$cycling, which is a prerequisite for sensory transduction [22]. Activation of $\beta_{1}$-AR has been shown in both epithelial cell types to increase the rate of $\mathrm{K}^{+}$secretion [23,24]. One may speculate that an elevated rate of $\mathrm{K}^{+}$secretion is necessary to enable the cochlea and the vestibular labyrinth to perform in the presence of an increased stimulatory load. Stimulation of $\mathrm{K}^{+}$secretion, however, may not be sufficient to enhance the performance of the inner ear. The performance of other inner ear cell types, in particular those involved in sensory transduction and transmission, may require stimulation 
and therefore may be endowed with $\beta$-AR. It is currently unknown whether $\beta_{1}$-AR are present in inner ear cells other than strial marginal cells and vestibular dark cells. Thus, the aim of the present study was to localize $\beta_{1}$-AR in the cochlea and the vestibular labyrinth.

$\beta_{1}$-AR were localized by confocal immunocytochemistry, characterized in Western immunoblots, and identified pharmacologically by measurements of cAMP production. Our observations confirm the presence of $\beta_{1}$-AR in strial marginal and vestibular dark cells and demonstrate for the first time the presence of $\beta_{1}$-AR in inner and outer hair cells, outer sulcus and spiral ganglion cells of the cochlea, as well as in transitional and supporting cells in cristae and maculae of the vestibular labyrinth. Taken together, $\beta_{1}$-AR are present in cells that are involved in auditory transduction and processing, as well as in cochlear and vestibular $\mathrm{K}^{+}$ cycling.

\section{Materials and Methods}

Animals

Adult, female gerbils (between 60 and $80 \mathrm{~g}$ ) were deeply anesthetized with pentobarbital (100 $\mathrm{mg} / \mathrm{kg}$ i.p.) and sacrificed by decapitation or transcardial perfusion with a nitrate solution followed by $3.7 \%$ formaldehyde/zinc (Electron Microscopy Science, Fort Washington, PA). All procedures involving animals were approved by the Institutional Animal Care and Use Committee at Kansas State University.

\section{Cryosections}

Methods for the preparation of cryosections are similar to those described previously [25]. In detail, the stapes and the round window membrane were removed and a small hole was drilled at the helicotrema of the cochlea. Both scalae were perfused with fixative $(0.5 \mathrm{ml}$ at $0.1 \mathrm{ml} /$ $\min$ at $4^{\circ} \mathrm{C}$ ) through the round and oval windows. The preparation was incubated in fresh fixative $\left(1 \mathrm{~h}\right.$ at $\left.4^{\circ} \mathrm{C}\right)$, decalcified in phosphate-buffered saline (PBS; in mM: $137 \mathrm{NaCl}, 1.8$ $\mathrm{KH}_{2} \mathrm{PO}_{4}, 2.7 \mathrm{KCI}, 10.1 \mathrm{Na}_{2} \mathrm{HPO}_{4}$, pH 7.4) containing $10 \%$ EDTA $\left(30 \mathrm{~h}\right.$ at $\left.4^{\circ} \mathrm{C}\right)$, and stepwise infiltrated with sucrose in PBS (10\%-30\% sucrose overnight at $\left.4^{\circ} \mathrm{C}\right)$. Finally, the preparation was incubated $\left(3 \mathrm{~h}\right.$ at $\left.4^{\circ} \mathrm{C}\right)$ in degassed embedding medium (O.C.T. Compound, Sakura/Tissue Tek, Torrance, CA). Cryosections of $8 \mu \mathrm{m}$ were prepared at $-23^{\circ} \mathrm{C}$ (Cryostat, Leitz, Wetzlar, Germany) and mounted on charged slides (ProbeOn Plus, Fischer, Pittsburgh, PA).

\section{Immunocytochemistry}

Cryosections were rehydrated in PBS (15 min at room temperature (RT)) and permeabilized and blocked ( $1 \mathrm{~h}$ at RT) with PBS-Triton ( $0.2 \%$ Triton-X in PBS) containing $10 \%$ goat serum (Sigma, St. Louis, MO). The rabbit polyclonal anti $\beta_{1}$-AR antibody (Santa Cruz SC-568, Santa Cruz, CA) was raised against a peptide mapping to the C-terminus (amino acids 446-464) of the mouse $\beta_{1}$-AR. This antibody was the only one out of 6 commercially available $\beta_{1}$-AR antibodies that is recommended for immunocytochemistry and Western immunoblotting. The antibody is reported to react specifically with $\beta_{1}$-AR of mouse, rat and human without any cross-reactivity with $\beta_{2}$ - or $\beta_{3}$-AR (Santa Cruz). The specificity of the antibody was verified using cryosections of the gerbil kidney. The staining pattern was similar to that reported in rat kidney [5] and absent when the antibody was pre-incubated with its immunizing peptide. The antibody was diluted (1:400; final concentration $0.5 \mu \mathrm{g} / \mathrm{ml})$ with PBS-Triton containing $1 \%$ goat serum with or without the antigenic peptide (1:80; final concentration of $2.5 \mu \mathrm{g} / \mathrm{ml}$ ) and incubated with the cryosections (overnight at $4^{\circ} \mathrm{C}$ ). Slides were washed with PBS-Triton and incubated (1 h at RT) with an Alexa 488-conjugated goat anti-rabbit antibody (Molecular Probes, Eugene, OR), which was diluted 1:300 in PBS-Triton containing 1\% goat serum. Slides were washed with PBS-Triton, embedded in FluorSave (Calbiochem, San Diego, CA) and coverslipped. Sections were examined with a confocal microscope (LSM 5 Pascal, Carl Zeiss, 
Jena, Germany), using a $488 \mathrm{~nm}$ argon laser and a 505-530 nm band-pass filter. All

immunocyto-chemical experiments were performed at least six times to ensure repeatability.

\section{Protein Preparations}

Methods for the isolation of cochlear and vestibular tissues have been described previously [23]. Temporal bones were dissected in $\operatorname{PBS}\left(4^{\circ} \mathrm{C}\right)$ and four fractions of inner ear tissues were isolated: 1) stria vascularis, 2) organ of Corti with the limbus and the outer part of the spiral lamina, 3) modiolus, and 4) vestibular labyrinth consisting of the utricle, ampullae and semicircular canals. We were meticulous to achieve a complete separation of the four fragments. Stria vascularis in particular peels off easily from the spiral ligament. Serial sections confirmed that stria vascularis including its basilar cell layer is removed completely from the spiral ligament. The organ of Corti with the limbus and the outer part of the spiral lamina is unrolled carefully from the modiolus under high magnification. It separates well and consistently from the adjacent modiolus fraction.

Inner ear tissues were homogenized separately by sonication $\left(45 \mathrm{~min}\right.$ at $\left.4^{\circ} \mathrm{C}\right)$ in lysis buffer (50 mM Tris-Cl, $2 \mathrm{mM}$ EDTA, $320 \mathrm{mM}$ sucrose, $\mathrm{pH}$ 7.4) with $2 \%$ protease inhibitor cocktail (Sigma, P8340). Insoluble cell debris was removed by centrifugation $(10,000 \times \mathrm{g}$ for $20 \mathrm{~min}$ at $4^{\circ} \mathrm{C}$ ) and the supernatant was stored $\left(-20^{\circ} \mathrm{C}\right)$. Heart and kidneys were homogenized, debris was removed by centrifugation and membranes were pelleted by ultracentrifugation $(60,000$ $\times \mathrm{g}$ for $45 \mathrm{~min}$ at $\left.4^{\circ} \mathrm{C}\right)$. Proteins were solubilized in resuspension buffer $(50 \mathrm{mM}$ Tris-Cl, 2 mM EDTA, $1 \%$ Triton X-100, pH 7.4) with $2 \%$ protease inhibitor cocktail. Concentrations were determined by a detergent-compatible protein assay (DC Protein Assay, Bio-Rad, Hercules, CA).

\section{Western Blotting}

Proteins ( $25 \mu \mathrm{g}$ per well) were denatured in the presence of $2.5 \%$ SDS and $2.5 \% \beta$ mercaptoethanol $\left(10 \mathrm{~min}\right.$ at $\left.70^{\circ} \mathrm{C}\right)$ and resolved by electrophoresis ( $100 \mathrm{~V}$ for $90 \mathrm{~min}$ ) in a 4 $15 \%$ polyacrylamide Tris-HCI gel (10-well mini-gel, Bio-Rad). A colored marker (Rainbow Molecular Weight Markers, Amersham Biosciences, Piscataway, NJ) was used to evaluate transfer efficiency and was calibrated against a precision marker (Precision Marker, BioRad) for estimation of molecular weight. Proteins were transferred ( $45 \mathrm{~min}$ at $15 \mathrm{~V}$ ) onto a nitrocellulose membrane $(0.45 \mu \mathrm{m}$ pores, Bio-Rad) using a semidry process (Trans-Blot SDDry Transfer Cell, Bio-Rad) and Towbin buffer (25 mм Tris, $200 \mathrm{~m}_{\mathrm{M}}$ glycine and 20\% methanol, $\mathrm{pH}$ 8.3). The membrane was blocked by incubation (1.5 $\mathrm{h}$ at RT) in PBS-Tween containing $0.1 \%$ Tween-20 and 5\% non-fat dry milk (Bio-Rad).

\section{Protein Detection}

Nitrocellulose membranes were incubated (overnight at $4{ }^{\circ} \mathrm{C}$ ) with the $\beta_{1}$-AR antibody (diluted 1:3,000; final concentration of $66 \mathrm{ng} / \mathrm{ml}$ with PBS-Tween containing $1 \%$ non-fat dry milk) with or without the antigenic peptide (1:600; final concentration of $333 \mathrm{ng} / \mathrm{ml})$. Membranes were washed with PBS-Tween and incubated ( $1 \mathrm{~h}$ at RT) with a horseradish peroxidaseconjugated donkey anti-rabbit antibody (Amersham Biosciences) that was diluted $(1: 3,000)$ with PBS-Tween containing 5\% non-fat dry milk. Membranes were then washed with PBSTween, treated with the chemiluminescent detection agent (ECL + Plus, Amersham Biosciences), exposed (2-10 min) to high performance chemiluminescence film (Hyper-film ECL, Amersham Biosciences) and developed immediately (X-Omat, Kodak).

\section{Deglycosylation}

Protein samples $(25 \mu \mathrm{g})$ were heat-denatured $\left(5 \mathrm{~min}\right.$ at $\left.100^{\circ} \mathrm{C}\right)$ in the presence of $2.5 \%$ SDS and $1 \% \beta$-mercaptoethanol. Deglycosylation was performed by incubation $\left(37^{\circ} \mathrm{C}, 3 \mathrm{~h}\right)$ in the 
presence of $1.25 \%$ Triton X-100 with either of the two N-glycosidases, 5 U PNGase F (PROzyme, San Leandro, CA) or $5 \mathrm{mU}$ Endo H (Sigma), or with the O-glycosidases $5 \mathrm{mU}$ sialidase A and $1.25 \mathrm{mU}$ endo-O-glycosidase (PROzyme). Deglycosylated proteins and their controls were then subjected to Western blotting.

\section{Production of CAMP}

For each experiment, stria vascularis and organ of Corti from 6 ears ( 3 gerbils) were pooled and separated into five apparently equal samples. The modioli were cut into half and five equal halves were used. Each of these five samples was treated either with saline (control), forskolin, isoproterenol, isoproterenol with ICI-118551, or isoproterenol with CGP-20712A. These samples were run in parallel to facilitate paired analysis. 14, 9 and 14 experiments were run for stria vascularis, organ of Corti and modiolus, respectively. After warming samples to $37^{\circ}$ $\mathrm{C}, \mathrm{NaCl}$ solution (in $\mathrm{m}_{\mathrm{M}}: 150 \mathrm{NaCl}, 1.6 \mathrm{~K}_{2} \mathrm{HPO}_{4}, 0.4 \mathrm{KH}_{2} \mathrm{PO}_{4}, 1 \mathrm{MgCl}_{2}, 0.7 \mathrm{CaCl}_{2}, 5$ glucose, $\mathrm{pH}$ 7.4) that contained $10^{-4}{ }_{\mathrm{M}}$ phosphodiesterase-inhibitor Ro-201724 (Calbiochem) was added with or without the antagonists ICI-118551 or CGP-20712A (Sigma). Preliminary experiments demonstrated that Ro-201724 did not interfere with the determination of cAMP production. Antagonist concentrations, which would allow a distinction between $\beta_{1}$ and $\beta_{2}$-AR subtypes, were determined by the transformed Cheng-Prusoff equation $I C_{50}=K_{\mathrm{DB}} *\left(1^{+} C / E C_{50}\right)$, where $I C_{50}$ is the concentration of the agonist, which causes a half-maximal inhibition of cAMP production, $K_{\mathrm{DB}}$ is the affinity constant for the antagonists $\left(K_{\mathrm{DB}}\right.$ for $\beta_{1}$-AR: ICI-118551 $=4.4$ $\times 10^{-8}$ and CGP-20712A $=>6.8 \times 10^{-12} \mathrm{M}$, and $K_{\mathrm{DB}}$ for $\beta_{2}$-AR: ICI-118551 $=1 \times 10^{-7}$ and CGP-20712A $\left.=>6 \times 10^{-6}{ }_{\mathrm{M}}(19 ; 24)\right), C$ is the concentration of the agonist isoproterenol (here $\left.10^{-5} \mathrm{M}\right)$, and $E C_{50}$ is the concentration of the agonist, which causes half-maximal cAMP production (stria vascularis: $5 \times 10^{-7} \mathrm{M}$ [23]). The $I C_{50}$ values for ICI-118551 were calculated to be for $\beta_{1}$ and $\beta_{2}$-AR $2 \times 10^{-6}$ and $5 \times 10^{-7}$ м and for CGP-20712A $4 \times 10^{-10}$ and $5 \times$ $10^{-4} \mathrm{M}$, respectively. Based on these calculations, the concentration of ICI-118551 was chosen to be $10^{-4} \mathrm{M}$, which would be expected to inhibit $\beta_{1}$ and $\beta_{2}$-AR, and the concentration of CGP-20712A was chosen to be $1 \times 10^{-5}$, which would be expected to inhibit only $\beta_{1}$ but not $\beta_{2}$-AR.

In a second step, $\mathrm{NaCl}$ solution with or without the agonists $\left(10^{-5}{ }_{\mathrm{M}}\right.$ forskolin or $10^{-5} \mathrm{M}$ isoproterenol (Sigma)) was added. After $12 \mathrm{~min}$ of incubation at $37^{\circ} \mathrm{C}$, the reaction was stopped by adding cold $\left(4^{\circ} \mathrm{C}\right)$ lysis buffer (Amersham). Tissue lysis was supported by sonication in ice water $(10 \mathrm{~min})$. Undissolved tissue fragments were removed by centrifugation and cAMP was measured in the supernatant with an immunoassay according to the manufacturer's protocol (non-acetylation protocol, cAMP assay, Amersham). The cAMP concentrations of the samples were calculated by comparing the data to a standard curve that was run in parallel to the samples.

Significance of changes in cAMP production was determined using a paired Student $t$-test. Significance was assumed on an error probability of less than $0.05(P<0.05)$.

\section{Results}

\section{Localization of $\beta_{1}$-AR}

$\beta_{1}$-AR were localized in cryosections of the inner ear by confocal immunohistochemistry.

Prominent $\beta_{1}$-AR immunoreactivity was found in the cochlea in strial marginal cells, inner and outer hair cells, outer sulcus cells, and spiral ganglion cells (Fig. 1A-B). Weaker staining was found in Reissner's membrane, the spiral ligament, spiral prominence and in endothelial cells of blood vessels located in the modiolus, the interscalar septae and the lateral wall.

Immunoreactivity of strial marginal cells appeared to be located in the densely infolded basolateral membranes rather than in apical membranes (Fig. $1 C$ and $D$ ). In addition to marginal cells, basal cells of stria vascularis appeared to be stained, although staining was weaker. Inner 
and outer hair cells displayed different staining patterns (Fig. $1 E$ ). Staining of outer hair cells appeared to be concentrated in the lateral membrane, whereas staining of inner hair cells appeared to occur in the basolateral membrane as well as in the cytosol. A punctate staining pattern was found in the synaptic region at the base of the inner hair cells (Fig. 1E). No staining was found in the region of the habenula perforata. Prominent staining was observed in spiral ganglia cells (Fig. $1 F$ ). No apparent difference was found between bigger spiral ganglion cells that presumably represent myelinated type-I cells and smaller cells that presumably represent unmyelinated type-II cells

Prominent $\beta_{1}$-AR immunoreactivity was found in the vestibular labyrinth in supporting cells in the cristae and maculae (Fig. $2 A, B$, and $D$ ). Weaker staining was found in vestibular dark cells and transitional cells (Fig. $2 C$ and $E$ ). No staining was found in vestibular hair cells, in the synaptic region underneath the hair cells, or in wall cells of the semicircular canals. The described immunoreactivities in the cochlea and vestibular labyrinth were absent when the $\beta_{1}$-AR antibody was pre-absorbed with the antigenic peptide (data not shown).

\section{Characterization of $\beta_{1}-A R$}

$\beta_{1}$-AR were characterized by Western immunoblotting. Heart and kidney, which are known to express $\beta_{1} \mathrm{AR}[5,7]$, served as positive controls and were used to develop procedures suitable for the minute protein samples that can be obtained from microdissected inner ear tissue fractions. The antibody recognized three bands in blots of heart and kidney membrane preparations with the apparent molecular weights of 160, 90 and $66 \mathrm{kDa}(n=3$; Fig. 3). Recognition of these bands was lost when the primary antibody was pre-absorbed with the antigenic peptide $(n=3)$. Two additional bands around $40 \mathrm{kDa}$ were considered unspecific since they were recognized by the pre-absorbed primary antibody. These observations suggest that the 160, 90 and $66 \mathrm{kDa}$ bands in kidney and heart contain $\beta_{1}$-AR protein.

Similar observations were made in blots of proteins obtained from the inner ear tissue fractions stria vascularis, organ of Corti, modiolus, and vestibular labyrinth. The antibody recognized bands with the apparent molecular weights of 160,100 and $55 \mathrm{kDa}$ ( $n=3$ for each; Fig. 3). Recognition of these bands was lost when the primary antibody was pre-absorbed with the antigenic peptide ( $n=3$ for each). Two additional bands around $40 \mathrm{kDa}$ were considered unspecific since they were recognized by the pre-absorbed primary antibody. These observations suggest that the 160,100 and $55 \mathrm{kDa}$ bands in inner ear tissue fractions contain $\beta_{1}$-AR protein.

The observation that multiple bands were recognized in heart, kidney and inner ear tissue fractions suggests that $\beta_{1}$-AR protein occurs in different modifications and complexes. The mobility of these apparent modifications and/or complexes in kidney was not altered by more rigorous denaturation $\left(15 \mathrm{~min}\right.$ at $\left.100^{\circ} \mathrm{C}\right)$, more forceful reduction $(0.4 \%$ DTT instead of $2.5 \%$ $\beta$-ME with addition of the alkylating reagent $0.1 \%$ iodoacetamide), or more thorough solubilization (addition of $2 \%$ Nonidet P-40 and $0.2 \%$ 3-[(3-cholamidopropyl)dimethylammonio]-1-propanesulfonate (CHAPS)).

Glycosylation is among the most common post-translational modifications of membrane proteins including $\beta$-AR (see Discussion). If $\beta_{1}$-AR proteins in the heart, kidney and inner ear tissue fractions are glycosylated, it would be expected that enzymatic deglycosylation would lead to a mobility shift.

Digestion of heart and kidney proteins with Endo H, which cleaves off high-mannose N-linked oligosaccharides, shifted the $160 \mathrm{kDa}$ band to $140 \mathrm{kDa}(n=3$, for each, Fig. 3). Pre absorption of the antibody with the antigenic peptide resulted in a loss of recognition of the $140 \mathrm{kDa}$ band, which suggests that the band contains $\beta_{1}$-AR protein ( $n=3$ for each; data not shown). Digestion 
of heart proteins with PNGase F, which cleaves off high-mannose as well as complex N-linked oligosaccharides, shifted the $160 \mathrm{kDa}$ band to $140 \mathrm{kDa}(n=3)$. Digestion of kidney proteins with PNGase F shifted the $160 \mathrm{kDa}$ band to the $140 \mathrm{kDa}$ band, and in addition, shifted the 90 $\mathrm{kDa}$ band to $80 \mathrm{kDa}(n=3)$. Pre-absorption of the antibody with the antigenic peptide resulted in a loss of recognition of the $140 \mathrm{kDa}$ band in kidney and heart and of the $80 \mathrm{kDa}$ band in kidney ( $n=3$ for each). Neither Endo H nor PNGase F shifted the unspecific bands around 40 $\mathrm{kDa}$.

Digestion of each of the inner ear tissue fractions with $\mathrm{N}$-glycosidases yielded similar results. Digestion with Endo H and PNGase F shifted the $160 \mathrm{kDa}$ bands to $140 \mathrm{kDa}(n=3$ for each; Fig. 3). Pre-absorption of the antibody with the antigenic peptide resulted in a loss of recognition of the $140 \mathrm{kDa}$ band (data not shown). Digestion with Endo H and PNG-ase F did not shift the $100 \mathrm{kDa}$ or the $55 \mathrm{kDa}$ bands.

Digestion with O-glycosidases sialidase A and Endo O did not result in shifts of the recognized bands in kidney $(n=3)$ or in inner ear tissue fractions (stria vascularis, modiolus, and vestibular labyrinth; $n=1$ for each). Positive control experiments were performed in parallel and entailed the deglycosylation of bovine fetuin protein $(n=3$; data not shown).

\section{Pharmacological Identification of $\beta$-AR}

$\beta_{1}$-Acetylcholine receptors signal mainly via an increase in the cytosolic cAMP concentration. Thus, functional $\beta_{1}$-AR can be identified pharmacologically by measuring cAMP production. If $\beta$-AR were present in the tissues, it would be expected that agonist isoproterenol at $10^{-5} \mathrm{M}$ would increase cAMP production. Forskolin $\left(10^{-5} \mathrm{M}\right)$, a direct stimulant of adenylyl cyclases, served as a positive control. If the predominant population of $\beta$-AR would consist of $\beta_{1}$-AR, it would be expected that agonist-induced cAMP production is prevented by the antagonists $10^{-4}{ }_{\mathrm{M}}$ ICI-118551 and $10^{-5}{ }_{\mathrm{M}}$ CGP-20712A. In contrast, if the predominant population of $\beta$ AR would consist of $\beta_{2}$-AR, it would be expected that agonist-induced cAMP production is prevented by $10^{-4}$ м ICI-118551 but not by $10^{-5}{ }_{\mathrm{M}}$ CGP-20712A.

Production of cAMP in stria vascularis and modiolus was low under control conditions and increased by forskolin and isoproterenol (Fig. 4). In contrast, cAMP production in the organ of Corti was comparably high under control conditions and increased by forskolin but not by isoproterenol. ICI-118551 and CGP-20712A reduced cAMP production in stria vascularis and organ of Corti, which is consistent with the presence of predominant populations of $\beta_{1}$-AR. In contrast, cAMP production in the modiolus was reduced by ICI-118551 but not by

CGP-20712A, which is consistent with the presence of a predominant population of $\beta_{2}$-AR.

\section{Discussion}

The most salient findings of the present study are 1) that $\beta_{1}$-AR are localized in stria marginal cells, outer sulcus cells, inner and outer hair cells, neuronal elements underneaththeinner hair cells, spiral ganglioncells and supporting cells neighboring vestibular hair cells; 2) that $\beta_{1}$-AR occur in all four inner ear tissue fractions as well as in heart and kidney in unglycosylated and high-mannose glycosylated complexes; and 3) that $\beta_{1}$-AR are the predominant functional $\beta$ $\mathrm{AR}$ in stria vascularis and organ of Corti, whereas $\beta_{2}-\mathrm{AR}$ are the predominant functional receptors in the modiolus.

\section{Localization and Identification of $\beta-A R$}

$\beta_{1}$-Acetylcholine receptors were localized by confocal immunocytochemistry in the cochlea and the vestibular labyrinth. Staining was considered specific since it was absent in the presence of the antigenic peptide. In addition, positive and negative controls were used to verify 
specificity. Staining of stria vascularis and vestibular dark cells was taken as a positive control since it is consistent with the pharmacological demonstration of functional $\beta_{1}$-AR in these tissues [23,24]. Further, the absence of staining in the semicircular canal epithelium, which contains functional $\beta_{2}$-AR but not $\beta_{2}$-AR [15], was taken as a negative control. The correspondence between staining and functional data validates the immunocytochemistry.

Staining of inner and outer hair cells was validated by a functional demonstration of $\beta_{1}$-AR in the organ of Corti (Fig. 1 and 4). Interestingly, cAMP production appeared elevated under control conditions. Addition of isoproterenol failed to stimulate cAMP production, and addition of the antagonists ICI-118551 and CGP-20712A caused a significant inhibition of cAMP production consistent with the presence of $\beta_{1}$-AR (Fig. 4). The observation that cAMP production appeared elevated under control conditions when compared to other tissue fractions may be due to the intrinsic presence of agonist. It is conceivable that sympathetic innervation provides a significant source of agonist in the organ of Corti tissue fraction.

The location of the $\beta_{2}$-AR that were identified by functional measurements in the modiolus (Fig. 4) and non-strial lateral wall tissues [19] remains undetermined due to the unavailability of a specific $\beta_{2}$-AR antibody.

\section{Characterization of $\beta$-AR Complexes}

$\beta_{1}$-AR have a theoretical molecular weight of $\sim 50 \mathrm{kDa}$. The specific band at $55 \mathrm{kDa}$, which was detected in all four inner ear tissue fractions, may thus be the $\beta_{1}$-AR. The theoretical molecular weight, however, can differ considerably from the apparent weight detectable by electrophoresis due to post-translational modifications such as N- and O-glycosylation or the formation of oligomeric complexes. Glycosylation, which can be tissue specific, is a modification that is typical for membrane proteins, including receptors.

The specific 100 and $160 \mathrm{kDa}$ bands found in inner ear tissues consisted of unglycosylated and high-mannose $\mathrm{N}$-glycosylated complexes that contained $\beta_{1}$-AR. Interestingly, $\mathrm{N}$-glycosylation and the formation of complexes appeared to be tissue-specific. The $90 \mathrm{kDa}$ complex-

glycosylated band was found in kidney but not in heart or the four inner ear fractions, whereas the $100 \mathrm{kDa}$ non-glycosylated complex was found in inner ear tissues but not in kidney. Nglycosylation of $\beta_{1}$-AR has been shown to prevent agonist-induced downregulation and to increase trafficking of $\beta$-AR to the cell surface [16]. Glycosylation in general has been shown to alter receptor trafficking, ligand binding, G-protein coupling, and desensitization [3,4]. It remained undetermined whether complexes consisted of multimeric $\beta_{1}$-AR or additional components and whether glycosylation was restricted to $\beta_{1}$-AR, which are known to contain one potential N-glycosylation site. The existence of oligomeric SDS-resistant complexes that contain dimeric heptahelical receptors has only recently been established $[1,6,18]$.

\section{$\beta_{1}-A R$ and $K^{+}$Cycling}

$\beta_{1}$-AR located in strial marginal and vestibular dark cells have recently been shown to increase the rate of $\mathrm{K}^{+}$secretion into endolymph $[23,24]$. Endolymph is the luminal fluid of the inner ear, which contains $\sim 150 \mathrm{~m}_{\mathrm{M}} \mathrm{K}^{+}$and provides a reservoir of $\mathrm{K}^{+}$, which serves as the charge carrier for sensory transduction in cochlea and vestibular labyrinth. $\mathrm{K}^{+}$is cycling within the cochlea and the vestibular labyrinth with strial marginal and vestibular dark cells engaging in $\mathrm{K}^{+}$secretion and several epithelial cell types mediating $\mathrm{K}^{+}$efflux from endolymph [22]. Efflux of $\mathrm{K}^{+}$from endolymph occurs in the cochlea via inner and outer hair cells and outer sulcus cells and in the vestibular labyrinth via hair cells and transitional cells $[11,13,21]$. The finely tuned balance between $\mathrm{K}^{+}$secretion and $\mathrm{K}^{+}$efflux is of utmost importance. An imbalance leads to a swelling of the endolymphatic fluid compartments as seen in Meniè re's disease or a collapse of these compartments as seen in Jervell and Lange-Nielsen syndrome. The 
observation that $\mathrm{K}^{+}$secretion is stimulated by $\beta_{1}-\mathrm{AR}$ in conjunction with the necessity of a balance between $\mathrm{K}^{+}$secretion and $\mathrm{K}^{+}$efflux leads to the hypothesis that $\beta_{1}$-AR in inner and outer hair cells, outer sulcus cells and vestibular transitional cells control the efflux of $\mathrm{K}^{+}$from endolymph. A well-synchronized stimulation of $\mathrm{K}^{+}$secretion and efflux via one receptor type may ensure a coordinated speeding of $\mathrm{K}^{+}$cycling.

\section{$\beta_{1}$-AR and Auditory Processing}

Patch clamp studies have shown that $\mathrm{K}^{+}$channels of inner $\left(I_{\mathrm{K}, \mathrm{f}}\right)$ and outer hair cell $\left(I_{\mathrm{K}}\right.$ and $\left.I_{\mathrm{k}, \mathrm{n}}\right)$ are activated by phosphorylation via protein kinase A $(9 ; 10)$. Thus, $\beta_{1}$-AR in inner and outer hair cells may activate these $\mathrm{K}^{+}$channels and cause an increase in $\mathrm{K}^{+}$efflux (10). Further, it is conceivable that $\beta_{1}$-AR in the inner hair cells facilitate glutamate release, as observed in cortical glutamatergic synapses $(8 ; 14)$.

In conclusion, we demonstrated that $\beta_{1}$-AR are located in the inner ear in epithelial cells that mediate sensory transduction and $\mathrm{K}^{+}$cycling and in neuronal cells that are involved in auditory transmission. Sympathetic stimulation of $\beta_{1}$-AR could lead to a facilitation of synaptic transmission and a well-balanced and coordinated enhancement of $\mathrm{K}^{+}$cycling, which would adapt the inner ear to a "fight or flight" situation.

\section{Acknowledgements}

The authors thank Cindy Chard-Bergstrom for her helpful recommendations in immunohistochemistry and Lili Maleki for reading the manuscript. The support by the Research Grant NIH-ROI-DC01098 from the National Institute on Deafness and Other Communication Disorders, National Institute of Health, is gratefully acknowledged.

\section{References}

1. Angers S, Salahpour A, Bouvier M. Biochemical and biophysical demonstration of GPCR oligomerization in mammalian cells. Life Sci 2001;68:2243-2250. [PubMed: 11358333]

2. Bai TR. $\beta_{2}$-adrenergic receptors in asthma: a current perspective. Lung 1992;170:125-141. [PubMed: 1351969]

3. Benallal M, Anner BM. Identification of organ-specific glycosylation of a membrane protein in two tissues using lectins. Experientia 1994;50:664-668. [PubMed: 8033974]

4. Benya RV, Kusui T, Katsuno T, Tsuda T, Mantey SA, Battey JF, Jensen RT. Glycosylation of the gastrin-releasing peptide receptor and its effect on expression, G protein coupling, and receptor modulatory processes. Mol Pharmacol 2000;58:1490-1501. [PubMed: 11093789]

5. Boivin V, Jahns R, Gambaryan S, Ness W, Boege F, Lohse MJ. Immunofluorescent imaging of $\beta_{1^{-}}$ and $\beta_{2}$ - adrenergic receptors in rat kidney. Kidney Int 2001;59:515-531. [PubMed: 11168934]

6. Hebert TE, Moffett S, Morello JP, Loisel TP, Bichet DG, Barret C, Bouvier M. A peptide derived from a $\beta_{2}$-adrenergic receptor transmembrane domain inhibits both receptor dimerization and activation. $\mathrm{J}$ Biol Chem 1996;271:16384-16392. [PubMed: 8663163]

7. Hellgren I, Sylven C, Magnusson Y. Study of the betal adrenergic receptor expression in human tissues: immunological approach. Biol Pharm Bull 2000;23:700-703. [PubMed: 10864018]

8. Herrero I, Sanchez-Prieto J. cAMP-dependent facilitation of glutamate release by $\beta$-adrenergic receptors in cere-brocortical nerve terminals. J Biol Chem 1996;271:30554-30560. [PubMed: 8940026]

9. Jagger DJ, Ashmore JF. Regulation of ionic currents by protein kinase A and intracellular calcium in outer hair cells isolated from the guinea-pig cochlea. Pfluegers Arch 1999;437:409-416. [PubMed: 9914397]

10. Jagger DJ, Ashmore JF. The fast activating potassium current, $I_{\mathrm{k}, \mathrm{f}}$, in guineapig inner hair cells is regulated by protein kinase A. Neurosci Lett 1999;263:145-148. [PubMed: 10213156]

11. Johnstone BM, Patuzzi R, Syka J, Sykova E. Stimulus-related potassium changes in the organ of Corti of guinea-pig. J Physiol 1989;408:77-92. [PubMed: 2778743] 
12. Laurikainen EA, Ren T, Miller JM, Nuttall AL, Quirk WS. The tonic sympathetic input to the cochlear vasculature in guinea pig. Hear Res 1997;105:141-145. [PubMed: 9083811]

13. Lee JH, Chiba T, Marcus DC. P2X2 receptor mediates stimulation of parasensory cation absorption by cochlear outer sulcus cells and vestibular transitional cells. J Neurosci 2001;21:9168-9174. [PubMed: 11717350]

14. Lopes LV, Cunha RA, Kull B, Fredholm BB, Ribeiro JA. Adenosine A2A receptor facilitation of hippocampal synaptic transmission is dependent on tonic $\mathrm{A}^{1}$ receptor inhibition. Neuroscience 2002;112:319-329. [PubMed: 12044450]

15. Milhaud PG, Pondugula SR, Lee JH, Herzog M, Lehouelleur J, Wangemann P, Sans A, Marcus DC. Chloride secretion by semicircular canal duct epithelium is stimulated via beta 2 -adrenergic receptors. Am J Physiol 2002;283:C1752-C1760.

16. Rands E, Candelore MR, Cheung AH, Hill WS, Strader CD, Dixon RA. Mutational analysis of $\beta$ adrenergic receptor glycosylation. J Biol Chem 1990;265:10759-10764. [PubMed: 2162359]

17. Rathz DA, Brown KM, Kramer LA, Liggett SB. Amino Acid 49 polymorphisms of the human $\beta_{1^{-}}$ adrenergic receptor affect agonist-promoted trafficking. J Cardiovasc Pharmacol 2002;39:155-160. [PubMed: 11791000]

18. Rios CD, Jordan BA, Gomes I, Devi LA. G-protein-coupled receptor dimerization: modulation of receptor function. Pharmacol Ther 2001;92:71-87. [PubMed: 11916530]

19. Schimanski S, Scofield MA, Wangemann P. Functional $\beta_{2}$-adrenergic receptors are present in nonstrial tissues of the lateral wall in the gerbil cochlea. Audiol Neurootol 2001;6:124-131. [PubMed: $11474138]$

20. Spoendlin H, Lichtensteiger W. The adrenergic innervation of the labyrinth. Acta Otolaryngol 1966;61:423-434. [PubMed: 5915897]

21. Valli P, Zucca G, Botta L. Perilymphatic potassium changes and potassium homeostasis in isolated semicircular canals of the frog. J Physiol 1990;430:585-594. [PubMed: 2086775]

22. Wangemann P. $\mathrm{K}^{+}$cycling and the endocochlear potential. Hear Res 2002;165:1-9. [PubMed: 12031509]

23. Wangemann P, Liu J, Shimozono M, Schimanski S, Scofield MA. $\mathrm{K}^{+}$secretion in strial marginal cells is stimulated via $\beta_{1}$-adrenergic receptors but not via $\beta_{2}$-adrenergic or vasopressin receptors. $\mathbf{J}$ Membrane Biol 2000;175:191-202. [PubMed: 10833529]

24. Wangemann P, Liu J, Shimozono M, Scofield MA. $\beta_{1}$-adrenergic receptors but not $\beta_{2}$-adrenergic or vasopressin receptors regulate $\mathrm{K}^{+}$secretion in vestibular dark cells of the inner ear. J Membrane Biol 1999;170:67-77. [PubMed: 10398761]

25. Whitlon DS, Szakaly R, Greiner MA. Cryoembedding and sectioning of cochleas for immunocytochemistry and in situ hybridization. Brain Res Brain Res Protoc 2001;6:159-166. [PubMed: 11223415]

26. Wiederholt M, Schmidt DK, Eggebrecht R, Zimmermann J, Fischer FH. Adrenergic regulation of sodium and chloride transport in the isolated cornea of rabbit and man. Graefes Arch Clin Exp Ophthalmol 1983;220:240-244. [PubMed: 6138298] 

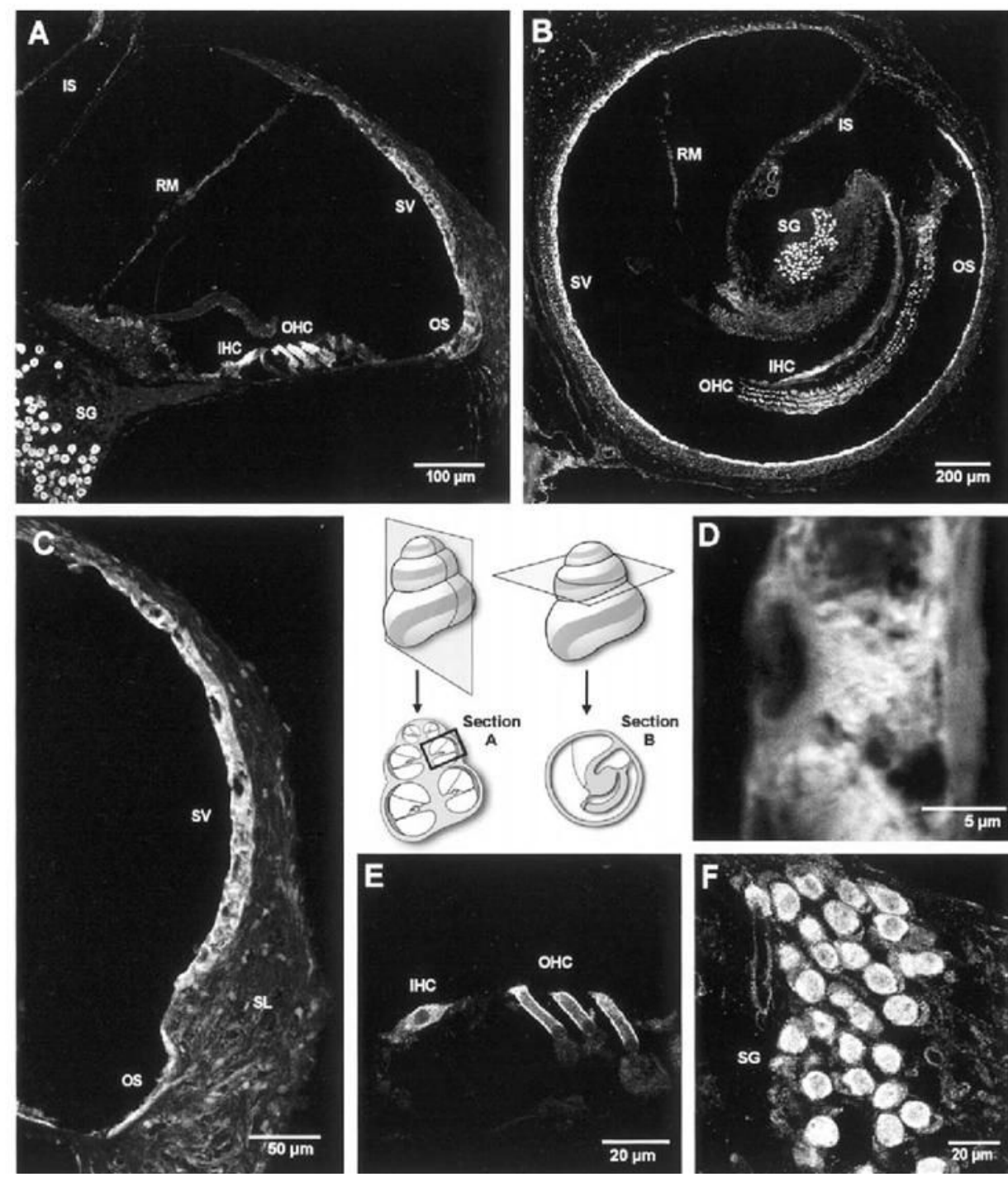

Fig 1.

Confocal immunocytochemistry of $\beta_{1}$-AR in $8 \mu \mathrm{m}$ cryosections of the gerbil cochlea. $(A)$ Overview of a cross-section of the middle turn showing predominant staining in stria vascularis, inner and outer hair cells and spiral ganglia cells. $(B)$ Overview of a horizontal section of the middle turn showing all structures of a complete turn. $(C)$ Cross section through the lateral wall. $(D)$ Stria vascularis. $(E)$ Organ of Corti. $(F)$ Spiral ganglion cells. Structures are identified as follows: $S V$, stria vascularis; $S L$, spiral ligament; $O S$, outer sulcus; $I H C$, inner hair cells; $O H C$, outer hair cells; $S G$, spiral ganglion; $R M$, Reissner's membrane; $I S$, inter-scalar septum. 

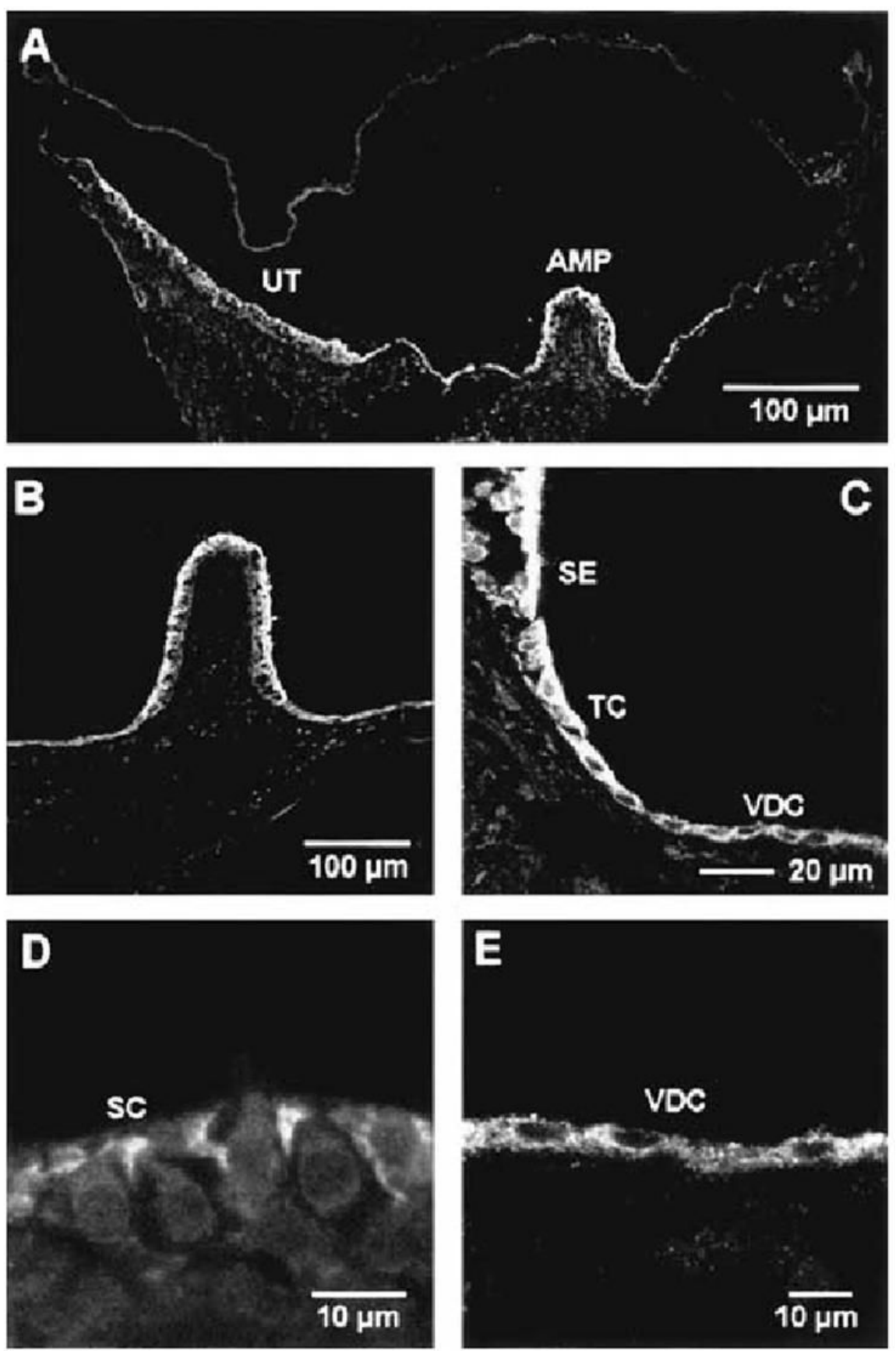

Fig 2.

Confocal immunocytochemistry of $\beta_{1}$-AR in $8 \mu \mathrm{m}$ cryo-sections of the gerbil vestibular labyrinth. (A) Overview of a cross section of the utricle and ampulla. (B) Crista ampullaris. $(C)$ Crista ampullaris with transitional and vestibular dark cells. $(D)$ Apex of the crista ampullaris. (E) Vestibular dark cell. Structures are identified as follows: $U T$, utricle; $A M P$, ampulla; $S E$, sensory epithelia; $T C$, transitional cells; $V D C$, vestibular dark cells; $S C$, supporting cells. 

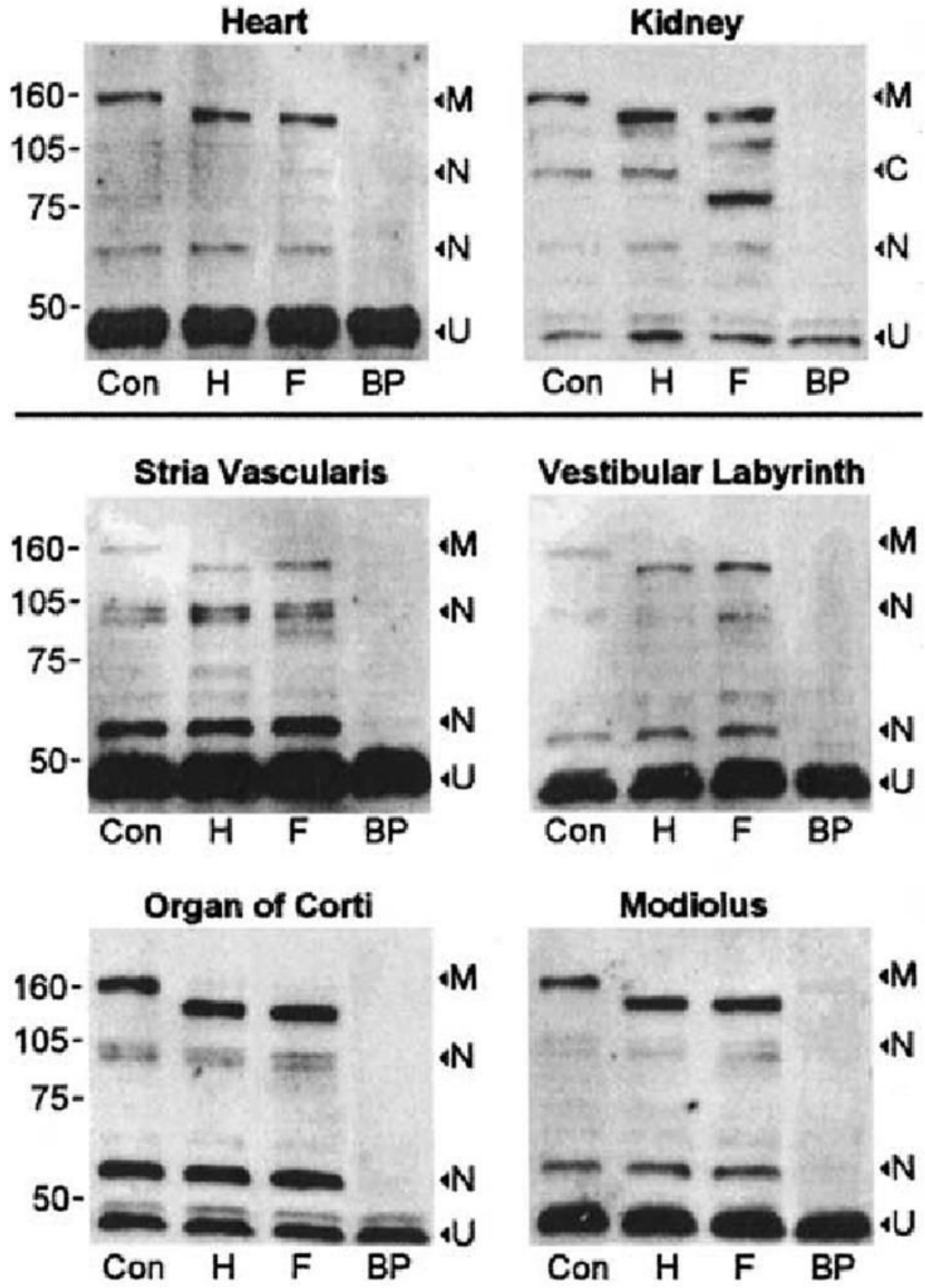

Fig 3.

Western immunoblotting and deglycosylation for $\beta_{1}$-ARs in membrane preparations of heart and kidney (positive control) and in homogenates of four inner ear tissue fractions. Protein samples $(25 \mu \mathrm{g})$ in each of the first lanes (Con) served as control and were not digested with $\mathrm{N}$-glycosidases. Samples in each second lane $(H)$ were digested with Endo-H, which cleaves high-mannose N-glycosylations. Samples in each third lane $(F)$ were digested with PNGase F, which cleaves high-mannose and complex N-glycosylation. Samples in each fourth lane $(B P)$ are identical to the first lane (Con) with the exception that the $\beta_{1}$-AR antibody was preincubated with the peptide it was raised against (blocking peptide). Thus, only the bands of 
unspecifically stained proteins remain. $M=$ high mannose glycosylation, $C=$ complex glycosylation, $N=$ non-glycosylated, $U=$ unspecific bands. 


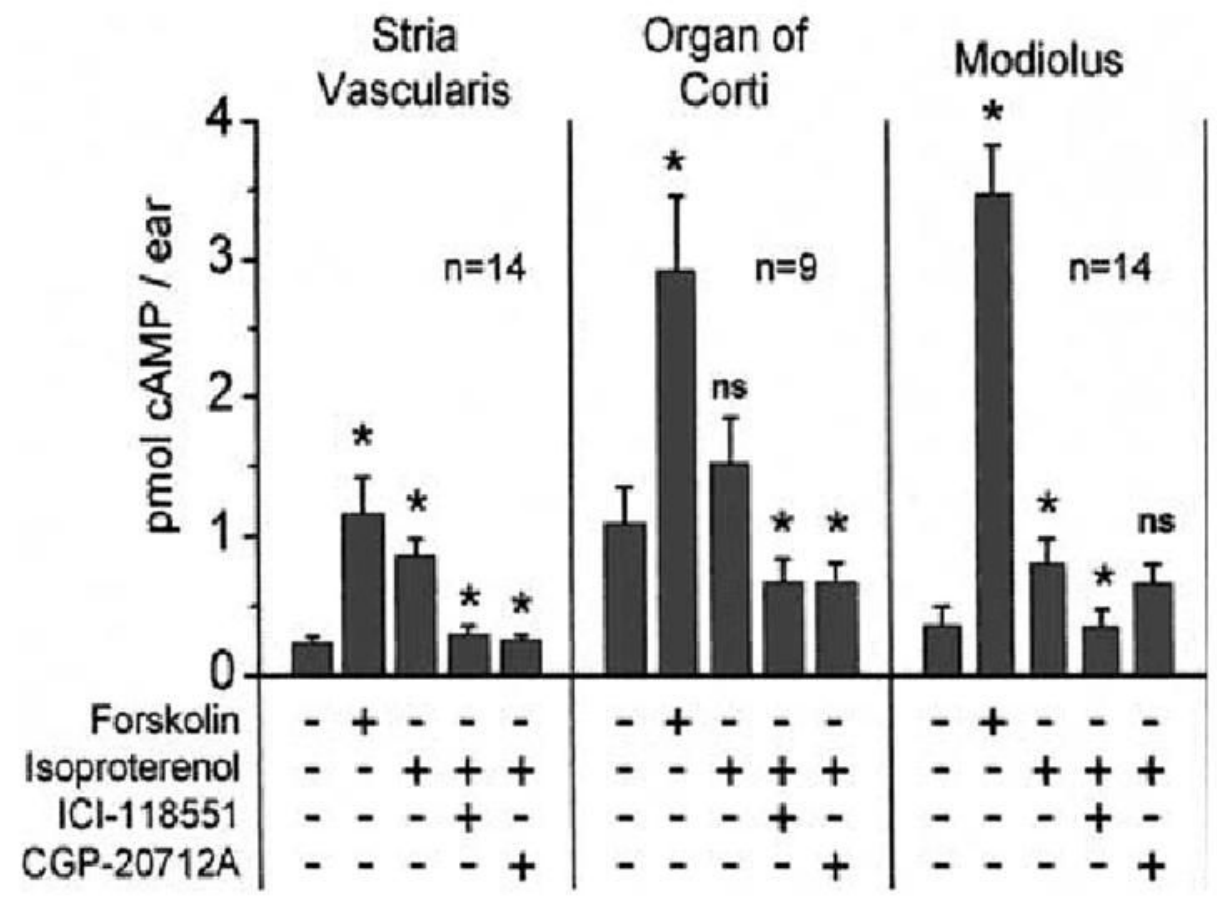

Fig 4.

Measurements of cAMP production in the three micro-dissected tissue fractions of the cochlea. Tissues were incubated with or without $10^{-5}{ }_{\mathrm{M}}$ forskolin or $10^{-5}{ }_{\mathrm{M}}$ isoproterenol, $10^{-4}{ }_{\mathrm{M}}$ ICI-118551, $10^{-5}{ }_{\mathrm{M}}$ CGP-20712A. Asterisk marks statistical significance $(P<0.05)$ and error bars indicate the standard error for each tissue. 